\title{
An Industrial Perspective on Environmentally Assisted Cracking of Some Commercially Used Carbon Steels and Corrosion- Resistant Alloys
}

\author{
YUGO ASHIDA, ${ }^{1,3}$ YUZO DAIGO, ${ }^{2,4}$ and KATSUO SUGAHARA ${ }^{2,5}$ \\ 1.-NHK International Corporation, 46855 Magellan Drive, Novi, MI 48377, USA. 2.-Hitachi \\ Metals MMC Superalloy Ltd., 1230 Kamihideya, Okegawa-shi, Saitama Prefecture 363-8510, \\ Japan. 3.-e-mail: yugo.ashida@nhkusa.com. 4.—e-mail: daigo@hitachi-metals-sa.co.jp. 5.—e-mail: \\ sugahara@hitachi-metals-sa.co.jp
}

Commercial metals and alloys like carbon steels, stainless steels, and nickelbased super alloys frequently encounter the problem of environmentally assisted cracking (EAC) and resulting failure in engineering components. This article aims to provide a perspective on three critical industrial applications having EAC issues: (1) corrosion and cracking of carbon steels in automotive applications, (2) EAC of iron- and nickel-based alloys in salt production and processing, and (3) EAC of iron- and nickel-based alloys in supercritical water. The review focuses on current industrial-level understanding with respect to corrosion fatigue, hydrogen-assisted cracking, or stress corrosion cracking, as well as the dominant factors affecting crack initiation and propagation. Furthermore, some ongoing industrial studies and directions of future research are also discussed.

\section{INTRODUCTION}

Environmentally assisted cracking (EAC) is one of the most common causes of failure in structures and components. For decades, the mechanisms of EAC have been intensively and extensively studied in chemical processing, in the oil and gas industry, and in nuclear power generation. ${ }^{1,2}$ Having a better understanding of EAC is vital for product life design or life extension across industry sectors. This article discusses on the EAC problem of some commercially used metals and alloys. It is especially focused on lowcost carbon steels (CS) and low-alloy steels (LAS) used for the automotive industry, and corrosion-resistant $\mathrm{Fe}-\mathrm{Cr}-\mathrm{Ni}$ alloys, such as stainless steels and Ni-based alloys used in a salt production environment and in a supercritical water environment. The purpose of this review is to prevent or mitigate the risk of EAC by raising awareness of the failure mode and the susceptible regime in these industrial applications.

Table I shows the EAC problems of each industrial application described in this article.

The information includes materials, the working environment, the corrosion type/cracking mode, the current industrial-level understanding of the root cause, controlling factors affecting the susceptibility to cracking, experimental approaches, and research efforts within each industry. In the following, we describe the EAC phenomena in the aforementioned industrial applications in three topical themes (categorized by application area).

\section{CORROSION AND CRACKING OF CARBON STEELS IN AUTOMOTIVE APPLICATIONS}

Low-cost carbon steels are used for automotive components, construction structures, bridges, and many other structures associated with daily life. A World Steel Association estimate shows that the automotive sector consumes roughly $12 \%$ of the overall steels in the world. ${ }^{3}$ On average, $900 \mathrm{~kg}$ of steel is used per vehicle, including $12 \%$ of highstrength carbon steels in the suspension. ${ }^{4}$ The corrosion of carbon steels caused by road salts and emissions was a serious problem during the early years of automotive development. ${ }^{5}$ In recent years, the corrosion and cracking problem was significantly improved through the advancement of coating technologies. ${ }^{5}$ Nevertheless, problems of localized corrosion, corrosion fatigue, and 
Table I. Industrial application and environmentally assisted cracking of commercially used Fe-Cr-Ni alloys

\begin{tabular}{|c|c|c|c|}
\hline Material & $\begin{array}{c}\text { Carbon steel/low-alloy } \\
\text { steel }\end{array}$ & Stainless steel & Ni-based alloy \\
\hline Industry sector ${ }^{\mathrm{a}}$ & Automotive & $\begin{array}{l}\text { Salt production/chemical } \\
\text { processing }\end{array}$ & $\begin{array}{l}\text { Salt Production/Super- } \\
\text { critical Water }\end{array}$ \\
\hline Chemical composition & $\mathrm{Fe}, \mathrm{C}$, minor elements & $\mathrm{Fe}, \mathrm{Cr}>10 \%$ & $\mathrm{Ni} \geq 50 \%, \mathrm{Cr}, \mathrm{Mo}$, etc. \\
\hline Unit price $^{\mathrm{b}}$ & $<1 \mathrm{USD} / \mathrm{kg}$ & 2-3 USD/kg & $>10 \mathrm{USD} / \mathrm{kg}$ \\
\hline Application & $\begin{array}{l}\text { Such as automotive sus- } \\
\text { pension coil springs }\end{array}$ & $\begin{array}{c}\text { Corrosion and heat resis- } \\
\text { tance }\end{array}$ & $\begin{array}{l}\text { Outstanding corrosion } \\
\text { and high-temperature } \\
\text { resistance }\end{array}$ \\
\hline Environment & $\begin{array}{l}\text { Moist/humid air with } \\
{\left[\mathrm{Cl}^{-}\right],\left[\mathrm{SO}_{4}{ }^{2-}\right], \text { etc. }}\end{array}$ & High $\left[\mathrm{Cl}^{-}\right]$concentrations & $\begin{array}{l}\text { Supercritical water with } \\
{\left[\mathrm{Cl}^{-}\right],\left[\mathrm{SO}_{4}^{2-}\right], \text { etc. }}\end{array}$ \\
\hline Corrosion type & $\mathrm{LC}, \mathrm{CF}, \mathrm{HAC}$ & SCC in bulk material & $\begin{array}{c}\text { LC, general corrosion, } \\
\text { SCC }\end{array}$ \\
\hline Root cause of failure & $\begin{array}{l}\text { LC promoted CF and } \\
\text { HAC from coating dam- } \\
\text { aged locations }\end{array}$ & $\begin{array}{l}\text { Low } \mathrm{pH} \text { of concentrated } \\
{\left[\mathrm{Cl}^{-}\right]}\end{array}$ & $\begin{array}{c}\text { CLSCC/SCC in SCW con- } \\
\text { taining anions }\end{array}$ \\
\hline Controlling factors & $\begin{array}{l}\text { Substrate, surface modi- } \\
\text { fication, pretreatment, } \\
\text { coating, coating damage }\end{array}$ & $\mathrm{pH},\left[\mathrm{Cl}^{-}\right]$ & $\begin{array}{c}\text { Dielectric constant of } \\
\text { water, species, and con- } \\
\text { centration of anions, elec- } \\
\text { tric potential }\end{array}$ \\
\hline Experimental approaches & SST, CCT & $\begin{array}{l}\mathrm{U} \text { bend testing in high- } \\
\text { temperature water con- } \\
\text { taining chloride }\end{array}$ & $\begin{array}{l}\text { Autoclave testing, slow } \\
\text { strain rate testing }\end{array}$ \\
\hline Required performance & $\begin{array}{c}\text { Improved fatigue/corro- } \\
\text { sion fatigue life and } \\
\text { resistant to delayed fail- } \\
\text { ure }\end{array}$ & Resistance to SCC & $\begin{array}{l}\text { Excellent resistance to } \\
\text { corrosion and SCC }\end{array}$ \\
\hline
\end{tabular}

hydrogen-assisted cracking in automotive components remain unsolved. The following section shows the typical case of automotive suspension coil springs.

\section{Coating and Coating Damage Caused Corrosion and Cracking of Coil Springs}

Carbon steels or low-alloy steels with pretreatment and resin powder coatings are being used for the production of coil springs, taking into account the balance between mechanical properties and the cost of materials and manufacturing. As shown in Fig. 1, the cross section of a coil spring wire consists of a metal substrate, a shot peened surface layer, a zinc phosphate $(\mathrm{ZnP})$ pretreatment layer, and an organic coating layer. There is a transition zone of mechanical properties between the metal substrate and the shot peened layer. The chemical composition is not changed in the metal transition zone. Nevertheless, the interface between metal and $\mathrm{ZnP}$ and the interface between $\mathrm{ZnP}$ and the coating provide favorable sites for corrosion when the bonding condition is an issue, and a crevice is easily formed in a moist/humid environment. Leidheiser ${ }^{6}$ systematically summarized the problem of corrosion on coating protected metals and pointed out that many problems remain unsolved. Ashida ${ }^{7,8}$ reported significant occurrence of localized corrosion from coating-damaged locations on coil springs.

It is important to understand localized corrosion under imperfect or damaged coatings. Localized corrosion has been studied for decades, and the current understanding of the mechanisms and critical factors has been reported. ${ }^{9-15}$ In the case of resin powder-coated carbon steels, susceptibility to corrosion is correlated to the properties of each protective layer, and the bonding conditions between different layers, as shown in Fig. 1. The main purpose of the shot-peened layer is to provide compressive stress on the surface to mitigate the initiation of fatigue cracks. In addition, the beneficial effect of compressive stress on localized corrosion is reported by Liu et al. ${ }^{16}$ and Peyre et al. ${ }^{17}$ The surface condition of shot-peened carbon steel affects the formation and adhesion of the $\mathrm{ZnP}$ layer and the organic coatings. Zinc phosphate crystals protect the metal surface from corrosion and provide a suitable interface for bonding with top coatings. ${ }^{18}$ The multiple chemical processes of forming the $\mathrm{ZnP}$ layer determines the composition/shape of particles, the surface coverage, and the layer thickness. The outermost layer of a single- or dual-powder coating provides a barrier on top, to prevent diffusion 

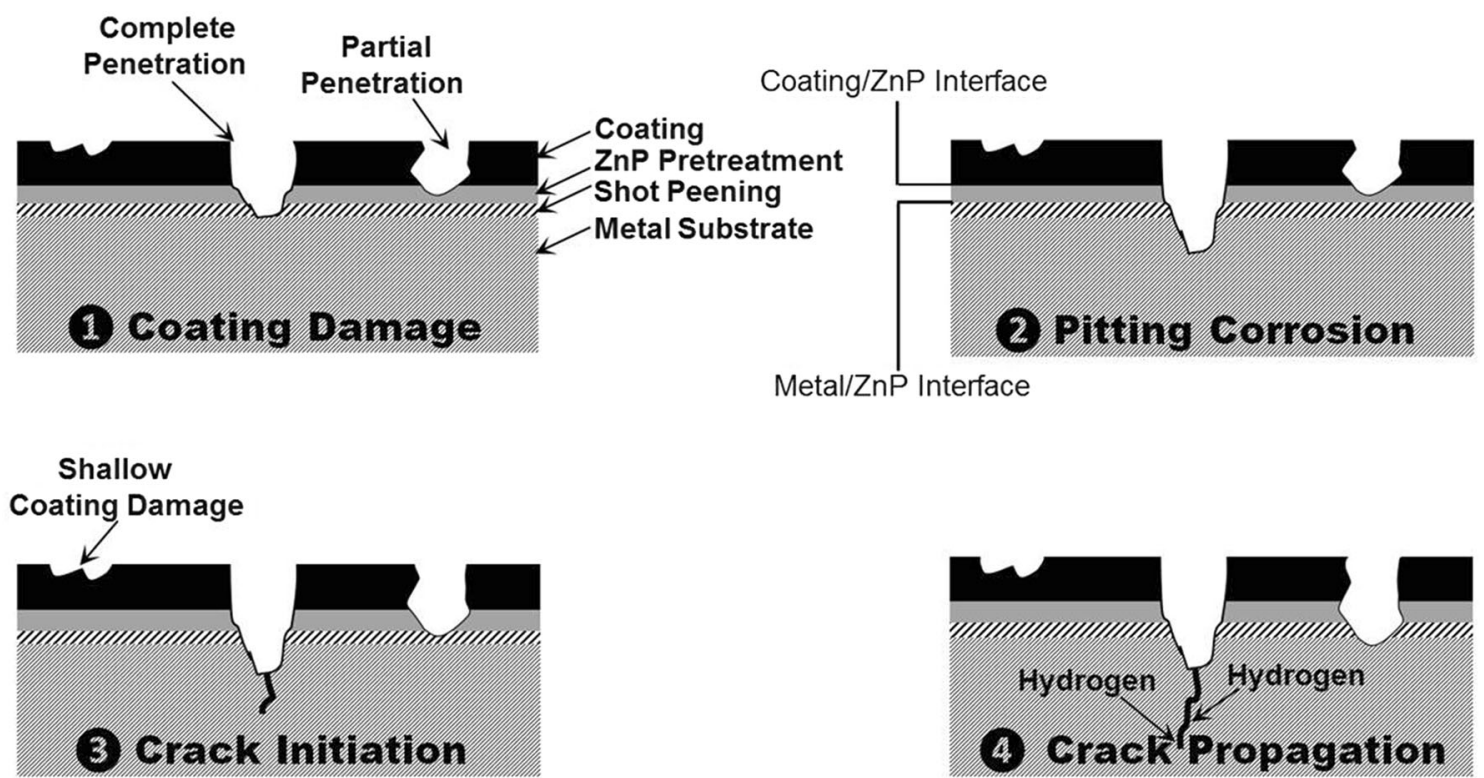

Fig. 1. Schematic overview shows the process of corrosion and cracking originated from coating damage.

processes and the occurrence of chemical and electrochemical reactions on the metal surface. Imperfect or damaged coating can cause corrosion and subsequent crack initiation from the corroded site.

Figure 1 shows a schematic overview of corrosion and cracking that originated from coating damage. The process of localized corrosion (i.e., pitting or crevice corrosion) involves the formation of coating damage, partial or complete penetration through coating and pretreatment, dissolution of the exposed substrate (i.e., the carbon steel substrate corrodes when no protective layers are provided), crack initiation at the bottom of a corrosion pit, and hydrogen-assisted crack propagation that leads to final failure. In addition, crevice corrosion occurs when adhesion is lost at the interfaces. Kendig and Mansfeld ${ }^{19,20}$ reported that penetration of the coating did not by itself cause failure of the coated metal. Nevertheless, loss of adhesion between the coating and the surface, as well as cohesive failure, was the major driving force causing final failure.

\section{Root Cause of Fatigue and Corrosion Fatigue}

Fatigue cracking initiates in both dry and wet environments under cyclic loading. In most cases of field failure, the root cause of cracking is related to metallurgical, physical, or corrosion defects on the surface, such as surface or subsurface inclusions, mechanical scratches or improper shot peening, or pitting and possibly crevice corrosion. Dry fatigue commonly starts from a metallurgical or physical defect. In the case of corrosion fatigue, inclusions and physical defects (e.g., a damaged coating) also provide favorite sites for the initiation of corrosion pits. Starting from these imperfect surfaces, small cracks form at the early stage of cracking. The formation of small cracks could represent a significant fraction of the life of a component. ${ }^{21}$ Subsequently, both aqueous environments and the mechanical driving force promote the propagation of corrosion fatigue.

\section{Hydrogen-Assisted Cracking of High-Strength Carbon Steels}

Hydrogen-delayed fracture or hydrogen-assisted cracking (HAC) of high- and ultrahigh-strength carbon steels have been studied for decades. According to Gangloff, ${ }^{22}$ hydrogen degradation of the crack propagation resistance of this type of alloy is categorized as either internal hydrogen-assisted cracking (IHAC) or hydrogen environment-assisted cracking (HEAC). As shown in Fig. 1, the effect of hydrogen is localized to the crack tip, regardless of the source of the hydrogen (i.e., introduced by manufacturing processes or through environmental exposure). In the case of suspension coil springs, the influences of tensile strength, hydrogen concentration, and applying stress mode (tension or torsion) on delayed fracture behavior have been experimentally investigated using SAE9254 steel with a tensile strength in the range between 1700 and $2000 \mathrm{MPa}^{23}$ It was found that the delayed fracture strength tends to decrease with the increment of diffusible hydrogen concentration, which is especially significant when the amount of hydrogen is less than 1 ppm. To ensure design integrity, these findings on hydrogen cracking are important to design engineers. 
Table II. U-bend test results in a boiling 45 wt.\% $\mathrm{MgCl}_{2}$ solution

\begin{tabular}{|c|c|c|c|}
\hline UNS no. & Time until cracking in $45 \% \mathrm{MgCl}_{2}$ at $154^{\circ} \mathrm{C}$ & Ni content, mass $\%$ & PRE number ${ }^{a}$ \\
\hline S30400 & $1-2$ & 8.8 & 18 \\
\hline S31600 & $1-2$ & 12.7 & 25 \\
\hline N08020 & 23 & 34.3 & 28 \\
\hline N08825 & 45 & 38.8 & 31 \\
\hline N06625 & 1000 , no cracking & 61.7 & 51 \\
\hline N10276 & 1000 , no cracking & 60.4 & 71 \\
\hline N06022 & 1000 , no cracking & 58.1 & 71 \\
\hline N06210 & 1000 , no cracking & 60.9 & 82 \\
\hline
\end{tabular}

${ }^{\mathrm{a} P R E}=[\mathrm{Cr}, \mathrm{wt} . \%]+3.3([\mathrm{Mo}, \mathrm{wt} . \%]+0.5[\mathrm{~W}, \mathrm{wt} . \%])$.

\section{ENVIRONMENTALLY ASSISTED CRACKING OF IRON- AND NICKEL-BASED ALLOYS IN SALT PRODUCTION AND PROCESSING}

Stress corrosion cracking of stainless steels in chloride containing environments is the most common failure mode of vessels and pipes in chemical processing and in the petrochemical industry. The mechanism and controlling factors affecting chloride stress corrosion cracking (CLSCC) have been systematically summarized in well-known corrosion textbooks. ${ }^{24,25}$ According to the empirical rule as shown in the Copson curve, ${ }^{24}$ the susceptibility of CLSCC increases with the nickel content from $0 \%$ to approximately $10 \%$. Nickel content from 8 to $10 \%$ is the typical range of traditional AISI 304 and 316 steels, that are in the range of maximum susceptibility. Nickel as an alloy element is said to have a beneficial effect on stress-corrosion cracking in chloride-laden environments in the case of nickel content being more than approximately $10 \%$. The CLSCC susceptibility decreases for lower nickel content (i.e., duplex stainless steels) or higher content than this range, as in the case of super-austenitic stainless steels or nickel alloys. Alloys containing more than 42 wt.\% nickel become immune to CLSCC. This article focuses particularly on the application of stainless steels and Ni-based alloys in extremely concentrated chloride environments.

In the Japanese salt manufacturing process, highsalinity water is obtained using an ion exchange membrane and distillation from sea water. The highest chloride concentration is around $35 \mathrm{wt} . \%,{ }^{26}$ and the highest process temperature is around $130^{\circ} \mathrm{C} .^{27}$ Type 316L SS (S31600) is used in the standard structural material of salt manufacturing plants. Although there is extensive research about SCC in water containing chloride, only a few studies have been conducted under salt manufacturing conditions. ${ }^{28}$

Tsugawa et al. ${ }^{29}$ evaluated CLSCC susceptibilities of alloys S31600, S31254, S32053, N08354, and N06022 by U-bend tests under simulated salt manufacturing conditions. The alloys S31254, S32053, and N08354 are classified as super austenitic stainless steels, and alloy N06022 is classified as a nickel- based, corrosion-resistant alloy. They reported that alloys with pitting resistance equivalent (PRE) numbers over 50, such as alloys N08354 and N06022, were proper structural materials for salt manufacturing plants with high chloride concentrations. The CLSCC susceptibilities of alloys S31600, S31254, and S32053, especially in a bittern are very high. The likely reason is that the high $\mathrm{MgCl}_{2}$ proportion of the chlorides in a bittern brings about low $\mathrm{pH}$ and a low $\mathrm{pH}$ buffer capacity; that is, low $\mathrm{pH}$ makes passivation films of the alloys unstable, and the low $\mathrm{pH}$ buffer capacity forms a low $\mathrm{pH}$ region locally.

Sugahara $^{30}$ evaluated CLSCC susceptibilities of iron-based and nickel-based alloys by carrying out U-bend tests in a boiling 45 wt. $\% \mathrm{MgCl}_{2}$ solution as shown in Table II.

Although all of the alloys containing less than $39 \%$ nickel cracked within a short time, all of the alloys containing around $60 \%$ nickel did not crack even after being held for $1000 \mathrm{~h}$. The results are in good agreement with the Copson curve.

\section{ENVIRONMENTALLY ASSISTED CRACKING OF IRON- AND NICKEL-BASED ALLOYS IN THE APPLICATION OF SUPERCRITICAL WATER}

The fourth state of water, supercritical water (SCW), is water at a higher pressure and a higher temperature than the critical point of water $\left(374.0^{\circ} \mathrm{C}\right.$ and $\left.22.1 \mathrm{MPa}\right)$. Supercritical water oxidation (SCWO) ${ }^{31-35}$ organic synthesis, ${ }^{36-44}$ hydrogen production and upgrading of heavy crude oil, ${ }^{45-48}$ and supercritical water reactor ${ }^{49,50}$ have been proposed as SCW applications. As SCW applications tend to be under extremely high corrosive conditions (e.g., high temperature and high pressure, high or low $\mathrm{pH}$, oxidizing or reducing environment, existence of chloride ion, etc.), it is easy to cause the SCC problem. Rebak ${ }^{51}$ found that N06625 and N102276 are susceptible to intergranular stress corrosion cracking (IGSCC) under SCWO conditions by conducting slow strain rate testing (SSRT). In this article, the results of testing under conditions of 
SCWO and reducing (including acidic and alkaline) are summarized on several more iron- and nickelbased alloys after Rebak's ${ }^{51}$ report.

\section{Corrosion and SCC in SCWO}

Harmful waste, such as chemical weapons and polychlorinated biphenyl (PCB), can be decomposed under SCWO conditions. It is possible to generate chloride and sulfuric ions in the process of decomposition. It is important to develop iron- and nickelbased alloys further with high performance of resistance to corrosion and SCC in SCWO. Accordingly, the effects of alloying elements on corrosion and cracking behavior of conventional and new alloys were investigated. Yakuwa et al. conducted corrosion tests of the Ni-(20-50 wt.\%)Cr-(0$10 \mathrm{wt} . \%)$ Mo alloy in SCW containing several anions $\left(\mathrm{Cl}^{-}=17,000 \mathrm{mg} / \mathrm{L}, \quad \mathrm{SO}_{4}{ }^{2-}=120 \mathrm{mg} / \mathrm{L}\right.$, etc. $)$ and cations $\left(\mathrm{Ca}^{+}=7,180 \mathrm{mg} / \mathrm{L}, \mathrm{K}^{+}=5,800 \mathrm{mg} / \mathrm{L}\right.$, etc. $)$ at $600^{\circ} \mathrm{C}$ and $25 \mathrm{MPa}$. They reported that alloys with chromium content of more than 35 wt.\% showed higher corrosion resistance than those with chromium content of less than $35 \mathrm{wt} . \%$, and that molybdenum improved corrosion resistance of the alloys. ${ }^{52}$ Hara et al. conducted corrosion tests of nickel-based and iron-based alloys in SCW containing $0.001 \mathrm{~mol} / \mathrm{kg}-\mathrm{HCl}+0.3 \mathrm{~mol} / \mathrm{kg}-\mathrm{O}_{2}$ at $500^{\circ} \mathrm{C}$ $29.4 \mathrm{MPa}$. They reported that the corrosion resistance of tested alloys strongly depended on chromium content, and that nickel-based alloys with chromium content of more than 20 wt. $\%$ and ironbased alloys with chromium content of more than 30 wt.\% became more corroded because of trans-passivation. ${ }^{53}$ Schorer et al. conducted corrosion tests of $\mathrm{Ni}-(20-40 \mathrm{wt} . \%) \mathrm{Cr}$ alloys in SCW containing $0.12 \mathrm{~mol} / \mathrm{kg}-\mathrm{HCl}+0.06 \mathrm{~mol} / \mathrm{kg}-\mathrm{O}_{2}$ at $410^{\circ} \mathrm{C}$ and 400 bar. They reported that Ni-30wt.\%Cr showed excellent corrosion, and that tungsten improved the corrosion resistance of the alloys. ${ }^{54}$ Watanabe et al. conducted corrosion tests on several types of nickelbased alloys and iron-based alloys in SCW containing sulfuric acid. They reported that chromium was a key element that improved the corrosion resistance of the alloys, and that iron also improved corrosion resistance of these alloys under oxidizing conditions. ${ }^{55}$ They also reported that corrosion conditions of subcritical water and high-pressure SCW are more severe than lower pressure SCW because density and dielectric constant of water of those conditions are higher than those of lower pressure SCW. Higher density and the electric constant of water enhanced electrochemical reactions. ${ }^{55}$ Fujisawa et al. conducted SSRT on S31603, N10276, N06625, and N06044 in SCW containing 0.001 and $0.01 \mathrm{~mol} / \mathrm{kg}-\mathrm{HCl}$ at $400^{\circ} \mathrm{C} 25 \mathrm{MPa}$. They reported that IGSCC susceptibility of tested alloys in $0.01 \mathrm{~mol} / \mathrm{kg}-\mathrm{HCl}$ was higher than in $0.001 \mathrm{~mol} /$
$\mathrm{kg}-\mathrm{HCl}$. They also reported that the susceptibility to IGSCC-containing higher chromium showed lower IGSCC susceptibility. ${ }^{56}$ In summary, the chromium content of the alloys is one of the key factors affecting corrosion and cracking behavior in SCWO.

In addition, Watanabe et al. evaluated SCC susceptibility of S31603 in the subcritical and SCW containing $0.01 \mathrm{~mol} / \mathrm{kg} \mathrm{H}_{2} \mathrm{SO}_{4}$ and reported that SCC susceptibility of S31603 was higher in SCW than in the subcritical. ${ }^{57}$ In SCW, the sulfate concentration did not affect SCC susceptibility of $\mathrm{S} 31603$ in the range of $0.0001-0.01 \mathrm{~mol} / \mathrm{kg}$ at $400^{\circ} \mathrm{C}$ and $25 \mathrm{MPa}{ }^{58}$ Nevertheless, it was found that a thick oxidized film formed along grain boundaries in a sulfate-containing environment. Water density was another factor affecting SCC susceptibility. Crack initiation in low-density water occurred more often than in high-density water. ${ }^{58}$

\section{Corrosion and SCC in Reducing (Acidic and Alkaline) SCW}

Adding hydrogen to SCW (i.e., reducing SCW) can be used for refining coal and oil sand at high $\mathrm{pH}$ and for hydrothermal synthesis at low $\mathrm{pH}$. Experimental data of SSRT on stainless steels and nickel-based alloys in reducing SCW were first reported by Nishida and Fujisawa et al. ${ }^{59,60}$ They evaluated the corrosion resistance of S31600, N10276, N06625, N06210, and N06044 under reducing $0.01-\mathrm{mol} / \mathrm{kg}-\mathrm{HCl}$ and $0.05-0.5-\mathrm{mol} / \mathrm{l}-\mathrm{NaOH}$ conditions. ${ }^{59,60}$ It was found that the corrosion resistance of nickel-based alloys showed better corrosion resistance over S31600 in all tested conditions, and that the corrosion rates of tested alloys tended to increase with increasing hydrogen partial pressure in SCW at low $\mathrm{pH}$ at $400^{\circ} \mathrm{C}$ and $25 \mathrm{MPa}$. They also showed that the Ni-Cr-Mo alloy demonstrated better corrosion resistance than a N06044 alloy that contains 44 wt.\% of chromium. Fujisawa et al. also showed that alloy N06210 demonstrated the best corrosion resistance in those alloys, and that chromium and molybdenum improved corrosion resistance of these alloys under the tested conditions. At high $\mathrm{pH}$, a similar corrosion behavior was observed. Regarding SCC susceptibility, Fujisawa et al. ${ }^{56}$ found that the IGSCC susceptibility of S31600 and N10276 decreased when $\mathrm{H}_{2}$ partial pressure was higher than $0.48 \mathrm{MPa}$. IGSCC susceptibility of S31600, N10276, N06625, N06210, and N06044 increased with increasing $\mathrm{NaOH}$ concentration at $400^{\circ} \mathrm{C}$ and $25 \mathrm{MPa}$. The SCC susceptibility of the tested alloy also decreased with increasing chromium content. In summary, as in SCWO, adding chromium to these alloys improved resistance to corrosion and SCC in reducing SCW. Molybdenum was also an effective element to increase corrosion and cracking resistance. 
(a)

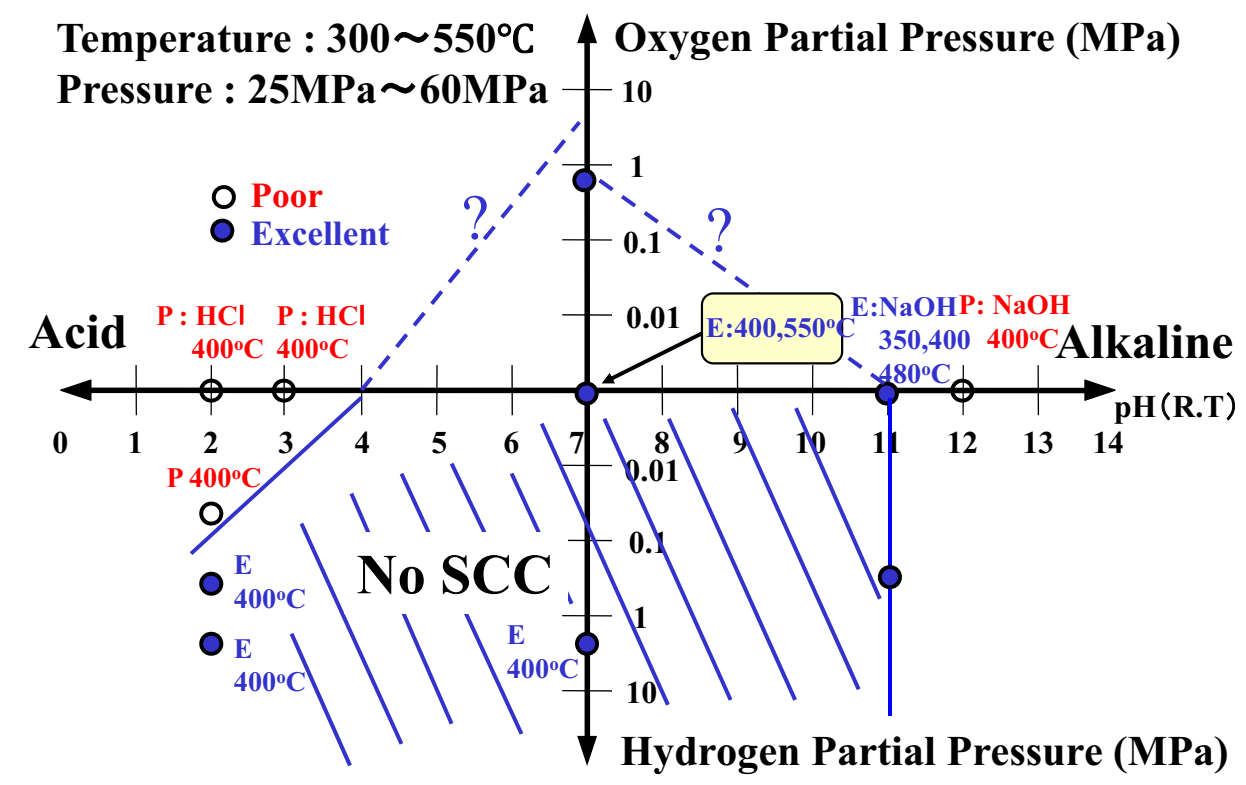

(b)

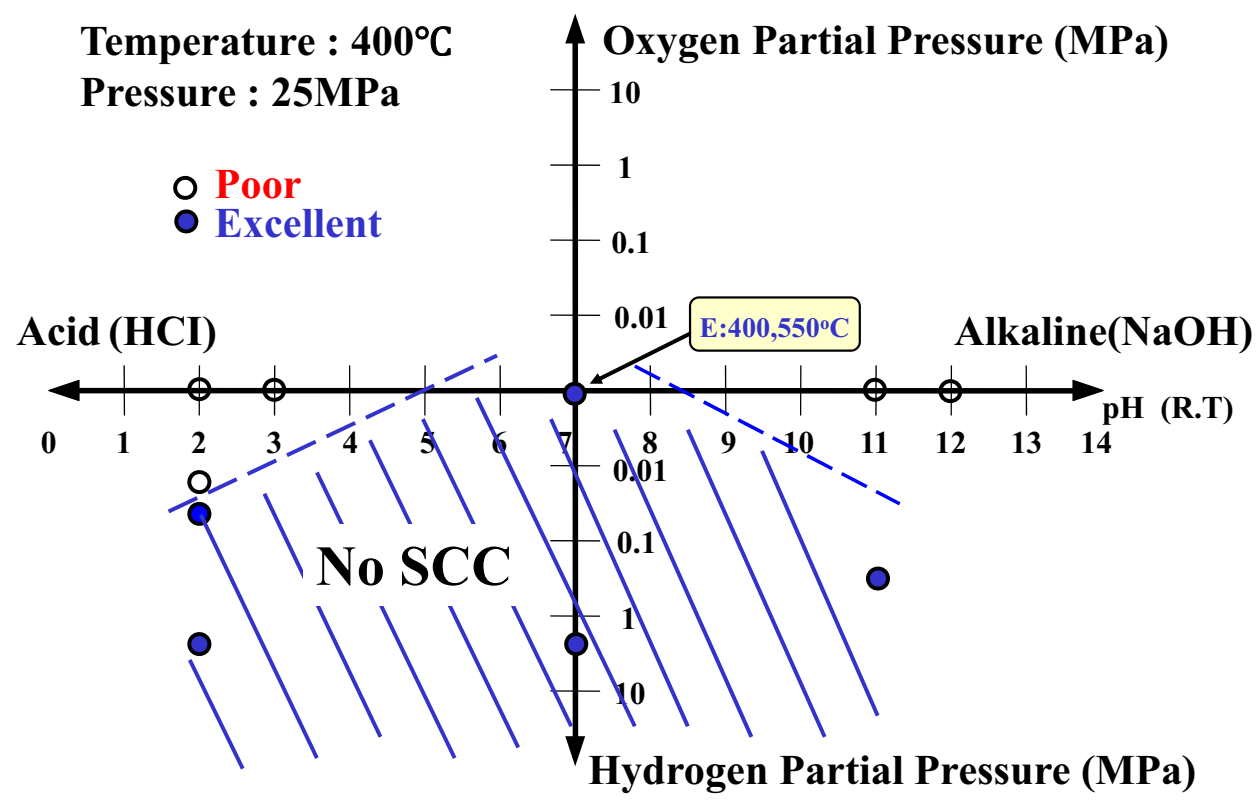

Fig. 2. SCC susceptibility maps of S31600 and N10276 in sub- and supercritical water: (a) SCC map of S31600 ${ }^{61}$ and (b) SCC map of N10276. ${ }^{61}$

\section{Mapping SCC in SCW}

Figure 2 shows applicable conditions of iron- and nickel-based alloys in SCW. Figure $2 \mathrm{a}$ and b comprise the SCC maps of S31600 and N10276, respectively, which generated from experimental data. The SCC susceptible region is larger under oxidizing conditions than under reducing conditions for the two alloys. Both S31600 and N10276 are immune to SCC in the $\mathrm{pH}$ range between 3 and 11 in reducing SCW. The two alloys can be used for the application of hydrogen production from biomass, which is in the $\mathrm{pH}$ range of $3.5-7.0$ and the hydrogen partial pressure range of $0.01-3.00 \mathrm{MPa}$ in reducing SCW.

\section{INDUSTRY-DIRECTED RESEARCH AND FUTURE DIRECTIONS}

For industrial applications, it is essential to identify root causes and key factors affecting the initiation and propagation of EAC. This article 
shows a typical range of variation in materialenvironment combination. In the case of a high corrosion rate $\left(\geq 10 \mu \mathrm{A} \mathrm{cm}\right.$ cm $\left.^{-2}\right)$ material, such as carbon steel, exposure to a mild aqueous environment can cause localized corrosion to accelerate the initiation of fatigue or corrosion fatigue significantly. For corrosion-resistant alloys with passivation behavior, the PRE number works as an indicator of the passive film broken down. Increasing the number of PRE delays the occurrence of pitting and effectively prevents SCC starting from pitting corrosion. In addition, mapping of a potential SCC susceptible region becomes more important for proactive design under extreme environments such as SCWO and reducing SCW. In general, to mitigate EAC in commercially used materials and structures, the research from industry includes developing new steels and alloys to improve EAC resistance, developing new testing technologies to identify the EAC regime, and increasing integrity and reliability to extend the life of components and structures. The future direction of industry-directed research will need to continuously focus on these areas to meet the requirements of next-generation production and applications.

Regarding new steel grades for coil spring manufacturing, Nakayama et al. ${ }^{62-65}$ proposed a method to improve corrosion fatigue resistance of ultrahighstrength steel by rust control and hydrogen trapping. In the development of UHS1900 steel designed with high strength and excellent corrosion fatigue resistance, rust composition control was achieved by the addition of copper, nickel, and chromium. Hydrogen trapping sites were introduced by the addition of titanium. In addition, Yoneguchi et al. ${ }^{66}$ reported the effectiveness of adding boron, niobium, and nickel for the improvement of corrosion fatigue strength and delayed fracture strength of coil spring steels. The development of the N06210 alloy previously described for application in highly concentrated chloride solutions and SCW environments is another example of improving EAC resistance. It's important to develop iron- and nickel-based alloys further with a high performance of resistance to corrosion and SCC in the SCW environment.

Industries are interested in developing new methodologies for testing corrosion and cracking. For automotive applications, Ashida et al ${ }^{67}$ showed the effectiveness of using coupled multielectrode array sensor (CMAS) technology to evaluate localized corrosion on $\mathrm{ZnP}$ pretreatment and powder coatings. Otake et al. ${ }^{68}$ used a compact neutron source for the nondestructive visualization of corrosion under coating films. The new technologies help to better understand the mechanism of corrosion and cracking under coatings, or at a damaged coating site. For testing in the SCW environment, it is important to enhance the capability of testing EAC, as well as to generate reliable data in the environment up to $30 \mathrm{MPa}$ of pressure and $600^{\circ} \mathrm{C} .^{31-50}$
To achieve both high performance and extended component life for industrial applications, it is crucial to evaluate EAC resistance along with material development, component design, and manufacture processing. The root cause of failure and the key factors affecting the engineering life of components must be identified by testing not only small specimens but also component-level performance. These concepts apply in the development of $2000-\mathrm{MPa}$ grade, advanced high-strength spring steel for the suspension component of lightweight vehicles. ${ }^{66,69}$ In the meantime, surface condition control before coating (including the control of soluble salt contamination ${ }^{70}$ ) is important for the management of the coating life cycle, which largely affects the initiation of localized corrosion and EAC in high-strength carbon and low-alloy steels.

\section{ACKNOWLEDGEMENTS}

The authors would like to thank Dr. Shinichi Nishizawa of NHK International Corporation and Mr. Toru Kobayashi of Hitachi Metals MMC Superalloy, Ltd. for their support in the preparation of this article. We thank Dr. Srujan Rokkam, the SCC Subject Editor, and the four anonymous reviewers for their comments.

\section{REFERENCES}

1. G.S. Was, Y. Ashida, and P.L. Andresen, Corros. Rev. 29, 7 (2011).

2. R.B. Rebak, in Stress Corrosion Cracking - Theory and Practice, ed. by V.S. Raja, T. Shoji (Woodhead Publishing, Cambridge, 2016), p. 273.

3. Trefis Team, Trends in steel usage in the automotive industry (Forbes.com, May 20, 2015), http://www.forbes. com/sites/greatspeculations/2015/05/20/trends-in-steelusage-in-the-automotive-industry. Accessed September 30, 2016 .

4. World Steel Association, Automotive (Website of the World Steel Association, 2016), https://www.worldsteel.org/Steelmarkets/Automotive.html. Accessed September 30, 2016.

5. U.S. Department of Transportation, Report No. FHWA-RD01-156, Federal Highway Administration, Washington, DC (2002).

6. H. Leidheiser Jr., Corrosion 38, 374 (1982).

7. Y. Ashida, CORROSION 2016 (NACE International, Houston, TX, 2016), Paper No. 7287.

8. Y. Ashida, CORROSION 2017 (NACE International, Houston, TX, 2017), Paper No. 9152.

9. G.S. Frankel and N. Sridhar, Mater. Today 11, 38 (2008).

10. G.S. Frankel, J. Electrochem. Soc. 145, 2186 (1998).

11. A. Turnbull, Corros. Sci. 23, 833 (1983).

12. C. Gabrielli, F. Huet, M. Keddam, and R. Oltra, Corrosion 46, 266 (1990).

13. C. Gabrielli and M. Keddam, Corrosion 48, 794 (1992).

14. H.-H. Strehblow, Werkst. Korros. 35, 437 (1984)

15. S.M. Sharland, Corros. Sci. 27, 289 (1987).

16. X. Liu and G.S. Frankel, Corros. Sci. 48, 3309 (2006).

17. P. Peyre, X. Scherpereel, L. Berthe, C. Carboni, R. Fabbro, G. Beranger, and C. Lemaitre, Mater. Sci. Eng. A 280, 294(2000).

18. H.S. Bender, G.D. Cheever, and J.J. Wojtkowiak, Prog. Org Coat. 8, 241 (1980).

19. M. Kendig, S. Tsai, and F. Mansfeld, Mater. Perform. 23, 37 (1984).

20. F. Mansfeld and M. Kendig, Report No. AD-A167281, Metallurgy \& Ceramics Program, Material Sciences Division, Office of Naval Research, Arlington, VA (1986). 
21. A. Turnbull, Proc. R. Soc. A 470, 20140254 (2014).

22. R.P. Gangloff, in Environment Induced Cracking of Materials (EICM-2), ed. by S Shipilov, R.H. Jones, J.-M Olive, R.B. Rebak (Elsevier Science, Oxford, UK, 2007), p. 141.

23. Research Committee on Delayed Fracture of Spring Steels, Bane Ronbunsyu 58, 41 (2013).

24. H.R. Copson, Effect of Composition on Stress Corrosion Cracking of Some Alloys Containing Nickel, Physical Metallurgy of Stress Corrosion Fracture (New York: Interscience Publishers, 1959).

25. H.S. Khatak and R. Baldev, Corrosion of Austenitic Stainless Steels: Mechanism, Mitigation and Monitoring (Materials Park: ASM International, 2002).

26. F. Yamada, M. Hidaka, T. Kaneko, and T. Fukumoto, Bull. Soc. Sea Water Sci. Jpn. 61, 141 (2007).

27. Y. Nagaoka and S. Aida, Bull. Soc. Sea Water Sci. Jpn. 27, 272 (1974).

28. N. Shinohara, Boshoku-Gijutsu 29, 497 (1980).

29. T. Tsugawa, Y. Watanabe, and H. Abe, Bull. Soc. Sea Water Sci. Jpn 65, 88 (2011).

30. K. Sugahara, J. Soc. Mater. Sci. Jpn 64, 57 (2015).

31. M. Modell, U.S. Patent, No. 4,338,199 (1982).

32. E.F. Gloyna and L. Li, Waste Manag. 13, 379 (1993).

33. Y. Arai, S. Koda, K. Nagahama, T. Sako, and K. Totigi, Fundamentals and Applications of Supercritical Fluids (Tokyo: Technosystem Co., Ltd., 2002)

34. Y. Akai, in International Symposium on Innovative Reaction Fields, Proceedings (2004), p. 173.

35. S. Baur, H. Schmidt, A. Kramer, and J. Gerber, J. Supercrit. Fluids 33, 149 (2005).

36. Y. Ikushima, Chem. Eng. 48, 173 (2003).

37. T. Sato, G. Sekiguchi, T. Adschiri, and K. Arai, Chem. Commun. 17, 1566 (2001).

38. T. Sato, G. Sekiguchi, T. Adschiri, and K. Arai, Ind. Eng. Chem. Res. 41, 3064 (2002).

39. T. Adschiri, R. Shibata, and K. Arai, J. Jpn. Petrol. Inst. 40, 291 (2002).

40. D.T. Chen, C.A. Perman, M.E. Riechert, and J. Hoven, J. Hazard. Mater. 44, 53 (1995).

41. T. Adschiri, O. Sato, K. Saito, and K. Arai, Kagaku Kogaku Ronbunshu 23, 505 (1997).

42. M. Sasaki, Z. Fang, T. Fukushima, T. Adschiri, and K. Arai, J. Ind. Eng. Chem. Res. 39, 2883 (2000).

43. T. Adschiri, S. Nagashima, H. Shibuichi, K. Arai, and M. Shishido, J. Jpn Inst. Energy 75, 742 (1996).

44. Y. Hakuta, T. Adschiri, and K. Arai, Chem. Eng. 45, 45 (2000).

45. D.S. Ross, J.E. Blessing, Q.Q. Nguyen, and G.P. Hum, Fuel 63, 1206 (1984).

46. H. Enomoto and M. Kinoshita, J. Inst. Saf. High Press. Gas Eng. 40, 14 (2003).

47. D. Yu, M. Aihara, and M.J. Antal Jr., Energy Fuels 7, 574 (1993).

48. M.J. Antal Jr., S.G. Allen, D. Schulman, X. Xu, and D. Robert Jr., Ind. Eng. Chem. Res. 39, 4040 (2000).

49. U.S. DOE Nuclear Energy Research Advisory Committee and the Generation IV International Forum, A Technology Roadmap for Generation IV Nuclear Energy Systems, Report No. GIF002-00, 1 December (2002) (http://nuclear. gov).
50. P. MacDonald, J. Buongiorno, C. Davis, and K. Weaver, Feasibility study of supercritical light water cooled reactors for electric power production. Final Report, DEFG0702SF22533, INEEL/EXT-04-02539, January (2005). (http:// wins.engr.wisc.edu/research/scw/intl/SCIEM-II/INEEL. pdf).

51. R.B. Rebak, CORROSION 2005 (NACE International, Houston, TX, 2005), Paper No. 05457.

52. H. Yakuwa, M. Miyasaka, and S. Iimura, CORROSION 2002 (NACE International, Houston, TX, 2002), Paper No. 02361.

53. N. Hara, S. Tanaka, S. Soma, and K. Sugimura, CORROSION 2002 (NACE International, Houston, TX, 2002), Paper No. 02358.

54. C. Schroer, J. Konys, J. Novotny, and J. Hausselt, CORROSION 2002 (NACE International, Houston, TX, 2002), Paper No. 02359.

55. Y. Watanabe. K. Shoji, T. Adchiri, and K. Sue, CORROSION 2002 (NACE International, Houston, TX, 2002), Paper No. 02355.

56. R. Fujisawa, K. Nishimura, T. Nishida, M. Sakaihara, Y. Kurata, and Y. Watanabe, CORROSION 2005 (NACE International, Houston, TX, 2005), Paper No. 05395.

57. Y. Watanabe, H. Abe, and Y. Daigo, CORROSION 2004 (NACE International, Houston, TX, 2004), Paper No. 04493.

58. H. Abe, Y. Daigo, Y. Watanabe, R. Fujisawa, and M. Sakaihara, in Proceedings of the 50th Japan Conference on Materials and Environments (Japan Society of Corrosion Engineering, Okinawa, Japan, 2003), D-115, p. 365.

59. R. Fujisawa, M. Sakaihara, Y. Kurata, and Y. Watanabe, Corros. Eng. Sci. Technol. 40, 244 (2005)

60. R. Fujisawa, K. Nishimura, T. Nishida, M. Sakaihara, Y. Kurata, and Y. Watanabe, CORROSION 2005 (NACE International, Houston, TX, 2005), Paper No. 05392.

61. New Energy and Industrial Technology Development Organization, Research and Development on Environmental Burden Reduction Technologies with Supercritical Fluids Report (2006), (http://www.nedo.go.jp/content/ 100096392.pdf).

62. T. Nakayama and H. Tanaka, Tetsu-to-Hagané 100, 1089 (2014).

63. T. Nakayama, T. Iwata, M. Nagao, M. Shimotusa, N. Ibaraki, and A. Inada, $R \& D$ Kobe Steel Eng. Rep. 47, 50 (1997).

64. T. Nakayama, Zairyo-to-Kankyo 48, 484 (1999).

65. M. Shimotsusa, N. Ibaraki, T. Ikeda, and T. Nakayama, Wire J. Int. 31, 78 (1998).

66. A. Yoneguchi, J. Schaad, Y. Kurebayashi, and Y. Ito, $S A E$ 2000 World Congress (SAE International, Warrendale, PA, 2000), Paper 2000-01-0098.

67. Y. Ashida, CORROSION 2017 (NACE International, Houston, TX, 2017), Paper No. 9011.

68. Y. Otake, M. Yamada, A. Taketani, H. Sunaga, and T. Nakayama, Isotope News 722, 8 (2014).

69. W. Hui, H. Dong, Y. Weng, J. Shi, and M. Wang, in Advanced Steels, ed. by Y. Weng, H. Dong, Y. Gan (Springer, Berlin, Germany, 2011), p. 137.

70. H. Peters, Mater. Perform. 45, 30 (2006). 